Arq. Bras. Med. Vet. Zootec., v.68, n.2, p.283-291, 2016

\title{
Acoustic radiation force impulse (ARFI) elastography of testicular disorders in dogs: preliminary results
}

\author{
[Elastografia acoustic radiation force impulse (ARFI) de afecções \\ testiculares em cães: resultados iniciais] \\ M.A.R. Feliciano ${ }^{1}$, M.C. Maronezi ${ }^{1}$, A.P.R. Simões ${ }^{1}$, G.S. Maciel ${ }^{1}$, L. Pavan ${ }^{1}$, B. Gasser ${ }^{1}$, \\ P. Silva ${ }^{1}$, R.R. Uscategui ${ }^{1}$, C.F. Carvalho ${ }^{2}$, J.C. Canola ${ }^{1}$, W.R.R. Vicente ${ }^{1}$ \\ ${ }^{1}$ Faculdade de Ciências Agrárias e Veterinárias - UNESP - Jaboticabal, SP \\ ${ }^{2}$ Universidade de São Paulo - USP - São Paulo, SP
}

\begin{abstract}
The aim of this study was to describe the use of acoustic radiation force impulse (ARFI) elastography in the evaluation of testicular disorders in dogs. Eighteen dogs with testicular disorders (thirty-six testicles) were assessed. Echotexture, size, contours and margins of testes were analysed by ultrasonography. Deformities and tissue stiffness (greyscale and homogenous or heterogeneous) were evaluated by qualitative elastography and shear velocity was determined quantitatively. Subsequent to orchiectomy, testicular samples were collected for histopathology analysis and thirty-six disorders were identified. Qualitative elastography revealed that normal healthy testicular tissues were homogenous and not pliable while the affected testicles had alterations in tissue stiffness and homogeneity. The values obtained for quantitative elastography of the testicular tissues were: normal $/$ healthy $-1.30 \pm 0.12 \mathrm{~m} / \mathrm{s}$; degenerated $0.97 \pm 0.08 \mathrm{~m} / \mathrm{s}$; atrophied - $2.00 \pm 0.35 \mathrm{~m} / \mathrm{s}$; hypoplastic $-0.82 \pm 0.2 \mathrm{~m} / \mathrm{s}$; cystic $-1.32 \pm 0.18 \mathrm{~m} / \mathrm{s}$; orchitis $2.68 \pm 0.42 \mathrm{~m} / \mathrm{s}$; interstitial cell tumours $-3.32 \pm 0.65 \mathrm{~m} / \mathrm{s}$; sertolioma $-2.99 \pm 0.07 \mathrm{~m} / \mathrm{s}$ and leydigoma $2.73 \pm 0.37$. ARFI elastography of abnormal testes proved to be an applicable and complementary technique in the diagnosis of testicular disease in dogs.
\end{abstract}

Keywords: canine, stiffness, testicular disease

\section{RESUMO}

O objetivo deste estudo foi descrever o uso da elastografia ARFI (acoustic radiation force impulse) para avaliar as afecções testiculares em cães. Dezoito cães com distúrbios testiculares (36 testículos) foram avaliados. Ecotextura, tamanho, contornos e margens dos testículos foram avaliados por meio da ultrassonografia modo-B. A presença de deformidades e a rigidez tecidual (escala de cinza; homogênea ou heterogênea) foram avaliadas pela elastografia qualitativa; e a velocidade de cisalhamento foi determinada pela avaliação quantitativa. Amostras dos tecidos testiculares foram coletadas após orquiectomia para o diagnóstico histopatológico. Após ultrassonografia, orquiectomia e histopatologia, foram identificados 36 distúrbios em tecidos testiculares. Durante a elastografia qualitativa, os tecidos normais apresentaram-se homogêneos e não deformáveis; os testículos alterados demonstraram alterações na rigidez tecidual e de sua homogeneidade. Para a elastografia quantitativa, os valores obtidos foram: tecidos normais - 1,30 $\pm 0,12 \mathrm{~m} / \mathrm{s}$; degenerados - 0,97 $\pm 0,08 \mathrm{~m} / \mathrm{s}$; atrofiados $2,00 \pm 0,35 \mathrm{~m} / \mathrm{s}$; hipoplásicos - 0,82 $\pm 0,2 \mathrm{~m} / \mathrm{s}$; cistos $-1,32 \pm 0,18 \mathrm{~m} / \mathrm{s}$; orquite $-2,68 \pm 0,42 \mathrm{~m} / \mathrm{s}$; tumores de

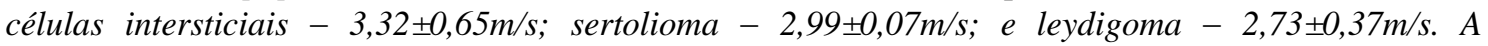
elastografia ARFI de testículos anormais em cães demonstrou ser uma técnica aplicável e complementar para o diagnóstico de doenças testiculares nessa espécie animal.

Palavras-chave: canino, rigidez, doença testicular

Recebido em 17 de março de 2015

Aceito em 15 de novembro de 2015

E-mail: marcusfeliciano@yahoo.com.br 


\section{INTRODUCTION}

The testicles, also defined as gonads, are the primary sexual organs of males and their function is to produce sperm and sexual hormones, especially testosterone. Studies on the normal testicular pattern of canines and on testicular alterations and their influence on fertility are important for early diagnosis of the main testicular disorders and in the selection of breeders (Kennedy and MacLachlan 2002; Feldman and Nelson 2004; Nelson and Couto 2006; Domingos and Salomão 2011).

Testicular ultrasonography in dogs enables the determination of the size, volume, position and internal constitution of the testicles. It aids the detection of small lesions or those inaccessible by palpation and provides details of the testicular tissue that cannot be obtained by radiography (Brandão et al. 2006; Davidson and Baker 2009; Goddi et al. 2012; Souza and Silva 2014). However, in most cases, ultrasonography is unable to differentiate the various canine testicular disorders and thus it must be used in conjunction with the animal's reproductive history, complimentary laboratory tests and invasive diagnostic techniques such as fine needle aspiration cytology, testicular biopsy and histopathology (Gradil et al. 2007).

Acoustic radiation force impulse (ARFI) elastography is an ultrasonographic technique that provides quantitative and qualitative measurements of tissue stiffness, with reduced inter-observer variability (Feliciano et al. 2015a). Qualitative ARFI creates a static greyscale map (elastogram) that represents the relative stiffness of the tissue in the scanned area and which can be compared to a corresponding conventional ultrasound scan. In general, lighter areas represent more pliable tissue than darker areas (D'Anastasi et al. 2011; Goddi et al. 2012). Quantitative ARFI creates propagating pressure waves that are capable of deforming the tissue quantitatively (pressure wave velocity of propagation or shear velocity). The velocity of propagation and attenuation of the waves are related to the stiffness and viscoelasticity of the tissue (Comstock 2011; Dudea et al. 2011).

In Veterinary Medicine, elastography has been used in the standardization of reference values of various tissues such as feline spleen (Feliciano et al. 2015b), canine spleen, liver and kidneys (Holdsworth et al. 2014) and in the differentiation of mammary neoplasms in female dogs (Feliciano et al. 2014). Feliciano et al. (2015a) conducted the first study on the use of the ARFI technique in the evaluation and standardization of reference values for canine testicles and obtained important results on the qualitative and quantitative analysis of healthy tissues in animals from different age groups.

In human obstetrics, elastography is a new ultrasound technique that has proved to be important in the detection of testicular alterations. According to some studies, the qualitative technique has $100 \%$ sensitivity in detecting testicular tumours when values indicate an increased stiffness of the testicular parenchyma. Furthermore, it enables the diagnosis of cysts, haematomas, calcifications, necrosis and other alterations that disrupt the homogeneity of the testicular tissue (Aigner et al. 2012; Huang and Sidhu 2012) as well as detect malignant lesions (Lorenz et al. 2000). In Veterinary Medicine, there are currently no studies on the use of this technique in the evaluation of testicular diseases in animals.

Analysis of the stiffness of canine testicular tissue by ARFI elastography provides a noninvasive alternative in the diagnosis of testicular alterations in small animals (Feliciano et al., 2015a). Given the importance of this new ultrasound technique in determining tissue stiffness and its recent application in small animal medicine, the aim of this study was to describe the use of ARFI elastography in the evaluation of abnormal testicular parenchyma in dogs.

\section{MATERIALS AND METHODS}

This study was approved by the Animal Ethics and Welfare Committee of the School of Agrarian and Veterinary Sciences of the Univ Estadual Paulista- UNESP, Jaboticabal-SP, Brazil (protocol 023705/12). Using a prospective study design, eighteen dogs with testicular disorders (thirty-six testicles), of various breeds and aged from 5 months to 12 years, were included in this study.

Anamnesis, general and specific physical examination (inspection of the scrotum and 
testicular and abdominal palpation), palpation of the regional lymph nodes and ultrasound scans (testicular and abdominal) were performed in all animals prior to inclusion in the study. Ultrasonography was used to identify ectopic testicular structures in the abdomen and subcutaneous and testicular lesions.

The animals from the present study did not have any physical conditions that could contraindicate surgical treatment (orchiectomy). Subsequent to ultrasound assessment and orchiectomy, the testicular tissues were subjected to histopathology analysis and classified according to the disorder observed.

The abdomen and scrotal sac were clipped and gel applied locally prior to ultrasound scanning. No sedation was needed.

Ultrasonography was carried out by a single experienced evaluator. B-Mode ultrasonography was performed with a $9.0 \mathrm{MHz}$ linear transducer using ACUSON S2000/SIEMENS ultrasound equipment (Siemens, Munich, Germany). The echotexture (homogeneous or heterogeneous; hypo, hyperechoic or mixed) of the parenchyma and the size (increased, decreased or normal), contours and margins (regular or irregular) of the testes (right and left) were assessed and categorised by longitudinal and transverse BMode ultrasound sections.

For elastography, qualitative and quantitative analyses were performed using the ARFI software and method (Virtual Touch Tissue Quantification) with a $9.0 \mathrm{MHz}$ linear matrix transducer (Feliciano et al. 2014).

Subsequent to B-mode ultrasonography, qualitative ARFI was performed to obtain greyscale images of the testicles in longitudinal sections. The images were evaluated for deformities, white (indicative of a less rigid, more elastic and pliable tissue) and dark areas (a more rigid, harder and less pliable tissue) (Feliciano et al. 2015a).

The quantitative analysis to determine mean shear velocity was performed after B-mode ultrasound scanning of the testes. To determine shear velocity, the calliper was positioned in the right and left testicular parenchyma and in focal lesions in the longitudinal sections (excluding the mediastinal portion). Six measurements were recorded for each area. The depth used for the testicular measurements was 0.5 to $1.0 \mathrm{~cm}$ (Feliciano et al. 2015a).

Animals were subjected to orchiectomy and samples of the testicular tissues collected for histopathology analysis. The macroscopic appearance of each testicular tissue was evaluated. Multiple fragments were fixed in 10\% buffered formaldehyde solution ( $\mathrm{pH}$ 7.4), processed and embedded in paraffin for routine histopathology analysis. Sections of $5 \mu \mathrm{m}$ were obtained using a microtome, mounted onto slides and stained with Hematoxylin \& Eosin. Light microscopy was used to analyse the histological characteristics of the tissues and for diagnosis of the disorders. The samples were assessed by a Senior Professor (PhD) of the School of Agrarian and Veterinary Sciences, Univ Estadual Paulista - UNESP, Department of Veterinary Pathology, Jaboticabal-SP, Brazil.

Non-parametric data (echotexture, echogenicity, size, greyscale images and the presence of deformities in the testes) were evaluated using descriptive analysis. The mean values and standard deviation obtained for shear velocity of the testicular tissue were compared to the reference values for healthy testicular tissue reported by Feliciano et al. (2015a).

\section{RESULTS}

Physical and specific examination of the 18 dogs with testicular alterations identified six cases of unilateral cryptorchidism (subcutaneous location), two cases of bilateral cryptorchidism (subcutaneous location), one case of bilateral cryptorchidism (abdominal location), one case of testicular enlargement and one case of decreased testicular size. Seven animals did not show any testicular alterations upon physical or specific examination.

Histopathology analysis of the thirty-six testicular tissues revealed normal (8), degenerated (15) and atrophied (3) testicles; testicular hypoplasia (2) and cyst (2); orchitis (3); interstitial cell tumours (2); sertolioma (1) and leydigoma (1).

The assessment of six testicles using B-mode ultrasound showed no abnormalities in the shape, 
size, margins or parenchyma surface (echogenicity and echotexture).

The following alterations in sonographic findings were observed in 30 testicular samples: 1) Testicular degeneration - normal or reduced size, gross echotexture, normal or hypoechoic echogenicity and regular or irregular contours and margins; 2) Testicular atrophy - reduced size, heterogeneous echotexture, mixed echogenicity (hyperechoic areas) and regular or irregular contours and margins; 3) Testicular hypoplasia - reduced size, homogeneous echotexture, hypoechoic echogenicity and regular contours and margins; 4) Testicular cysts - cystic structures $<1 \mathrm{~cm}$ in diameter; 5) Orchitis - increased size, heterogeneous echotexture, mixed echogenicity (hypoechoic, hyperechoic and anechoic areas), irregular contours and margins, mediastinal obliteration and hydrocele; 6) Interstitial cell tumour - increased size, heterogeneous echotexture, diffuse pattern with mixed echogenicity (hypoechoic and hyperechoic areas) or focal hypoechoic lesion
$(0.96 \mathrm{~cm}$ of diameter), regular or irregular contours and margins and mediastinal obliteration; 7) Sertolioma - normal size, heterogeneous echotexture, focal hypoechoic lesion $(0.98 \mathrm{~cm}$ of diameter $)$, regular contours and margins; and 8) Leydigoma - normal size, heterogeneous echotexture, diffuse pattern with mixed echogenicity (hypoechoic and hyperechoic areas), irregular contours and margins and mediastinal obliteration.

Qualitative elastography showed that healthy testicular parenchyma was homogenous (midgrey) and not pliable. On the other hand, abnormal testicles were stiff and not homogeneous (Table 1) (Figure 1 and 2).

For quantitative elastography, the mean shear velocity value of normal healthy testicles was $1.30 \pm 0.12 \mathrm{~m} / \mathrm{s}$. The results obtained for shear velocity of abnormal testicles are detailed in Table 1 (Figure 3 and 4).

Table 1. Characteristics of tissue stiffness and shear velocity of abnormal testicles of dogs evaluated by qualitative and quantitative elastography

\begin{tabular}{ccc}
\hline Disorders & Characteristics of tissue stiffness & Shear velocity $(\mathrm{m} / \mathrm{s})$ \\
\hline Testicular degeneration & heterogeneous parenchyma, not pliable & $0.97 \pm 0.08$ \\
Testicular atrophy & heterogeneous parenchyma, not pliable & $2.00 \pm 0.35$ \\
Testicular hypoplasia & heterogeneous parenchyma, light-grey, not pliable & $0.82 \pm 0.2$ \\
Testicular cysts & areas in mosaic & $1.32 \pm 0.18$ \\
Orchitis & heterogeneous parenchyma, not pliable & (peri-cystic region) \\
Interstitial cell tumour & heterogeneous parenchyma, not pliable, with hard \\
focal lesion & $2.68 \pm 0.42$ \\
Sertolioma & heterogeneous parenchyma, not pliable, with hard \\
focal lesion & $3.32 \pm 0.65$ \\
Leydigoma & heterogeneous parenchyma, not pliable & $2.99 \pm 0.07$ \\
& & $2.73 \pm 0.37$ \\
\hline
\end{tabular}

$\mathrm{m} / \mathrm{s}$ : meters per second 

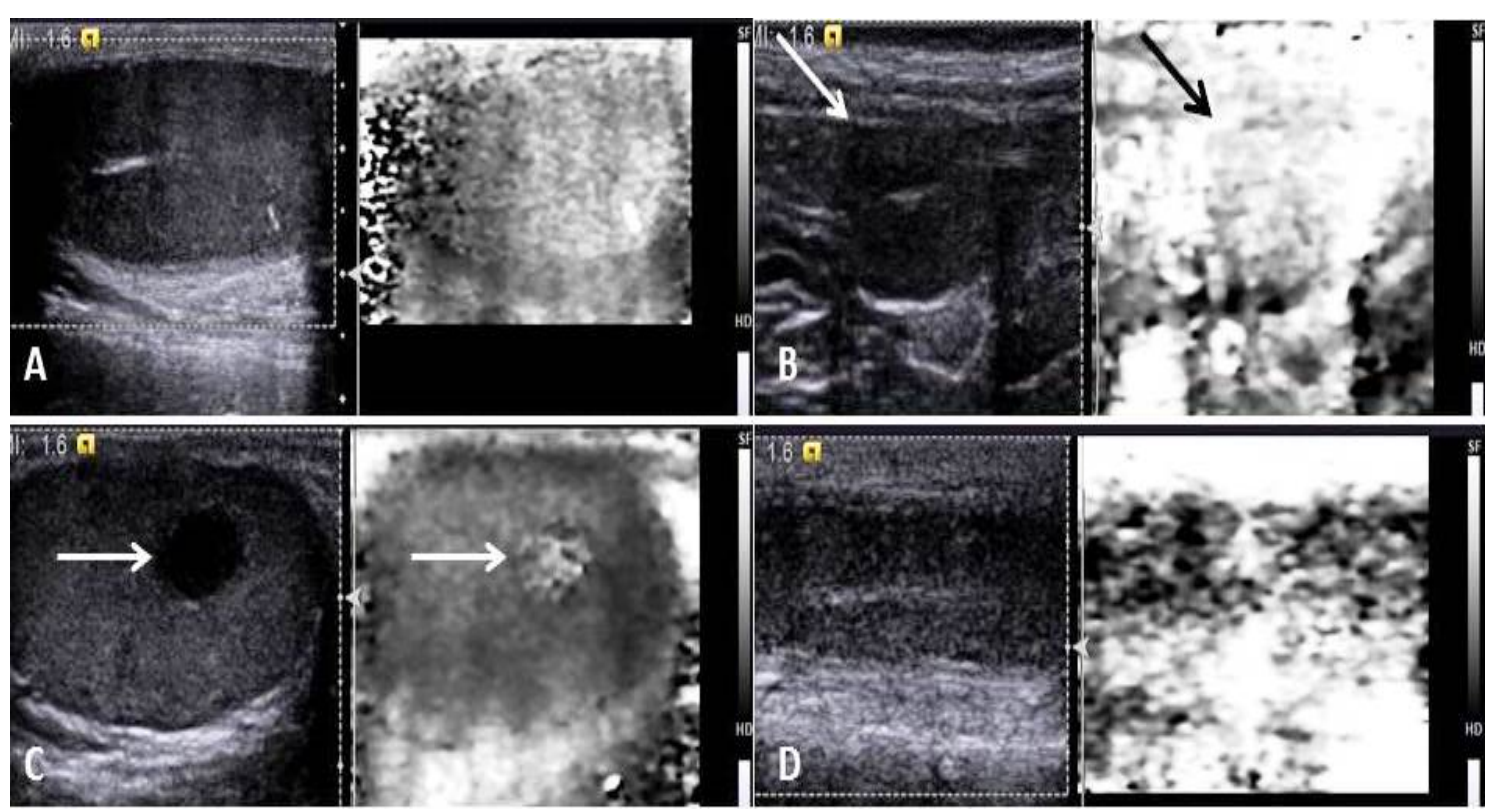

Figure 1. Qualitative ARFI elastography image illustrating the stiffness in testicular disorders in dogs: (A) heterogeneous parenchyma and not pliable, testicular degeneration; (B) heterogeneous parenchyma (arrows), light grey and not pliable, testicular hypoplasia; (C) areas in mosaic, testicular cysts (arrows) and (D) heterogeneous parenchyma and not pliable, testicular atrophy.
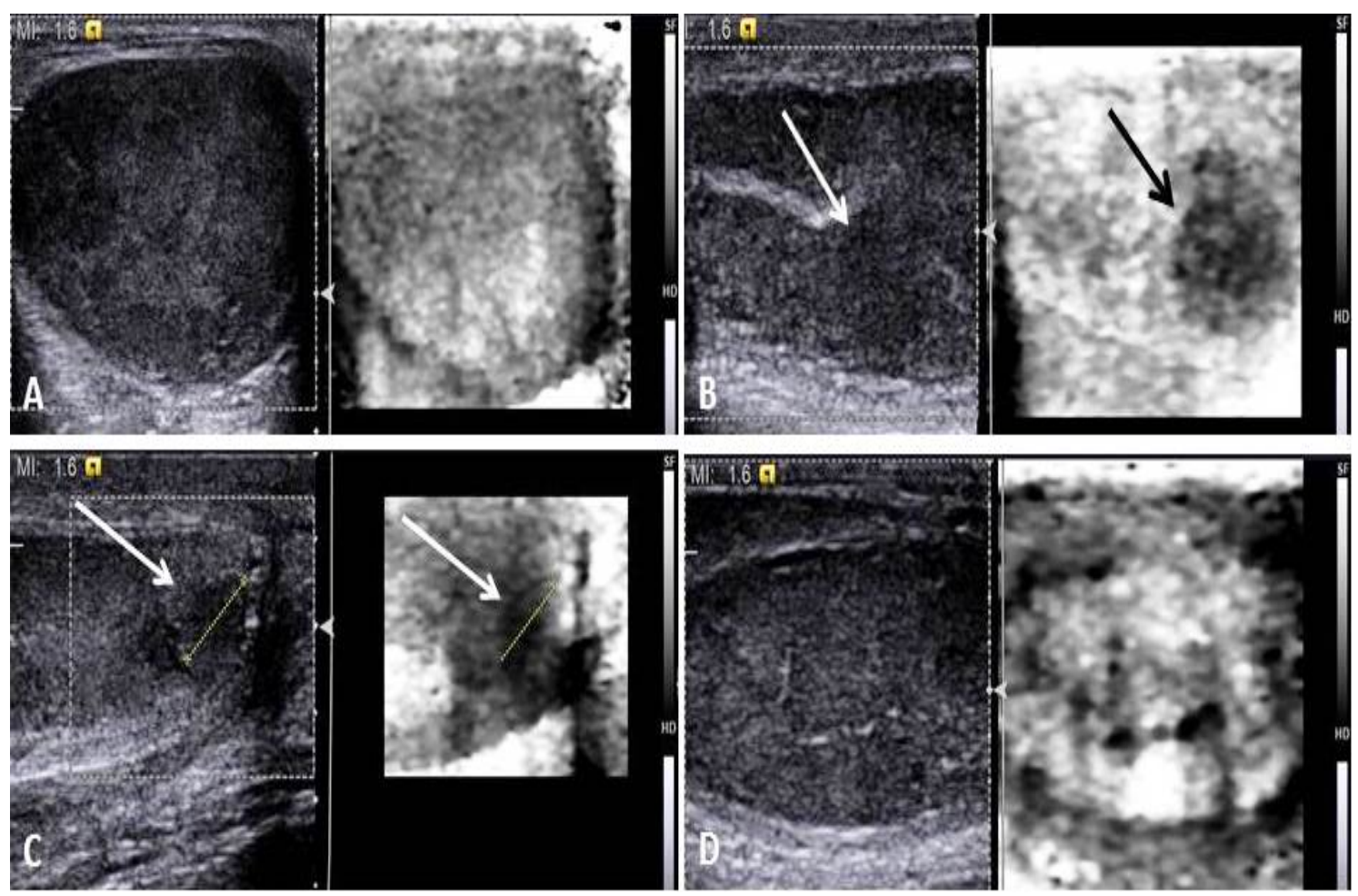

Figure 2. Qualitative ARFI elastography images illustrating the stiffness in testicular disorders in dogs: (A) heterogeneous parenchyma and not pliable, orchitis; (B) heterogeneous parenchyma with hard focal lesion and not pliable (arrows), interstitial cell tumour; (C) heterogeneous parenchyma with hard focal lesion and not pliable, sertolioma (arrows); and (D) heterogeneous parenchyma and not pliable, leydigoma. 

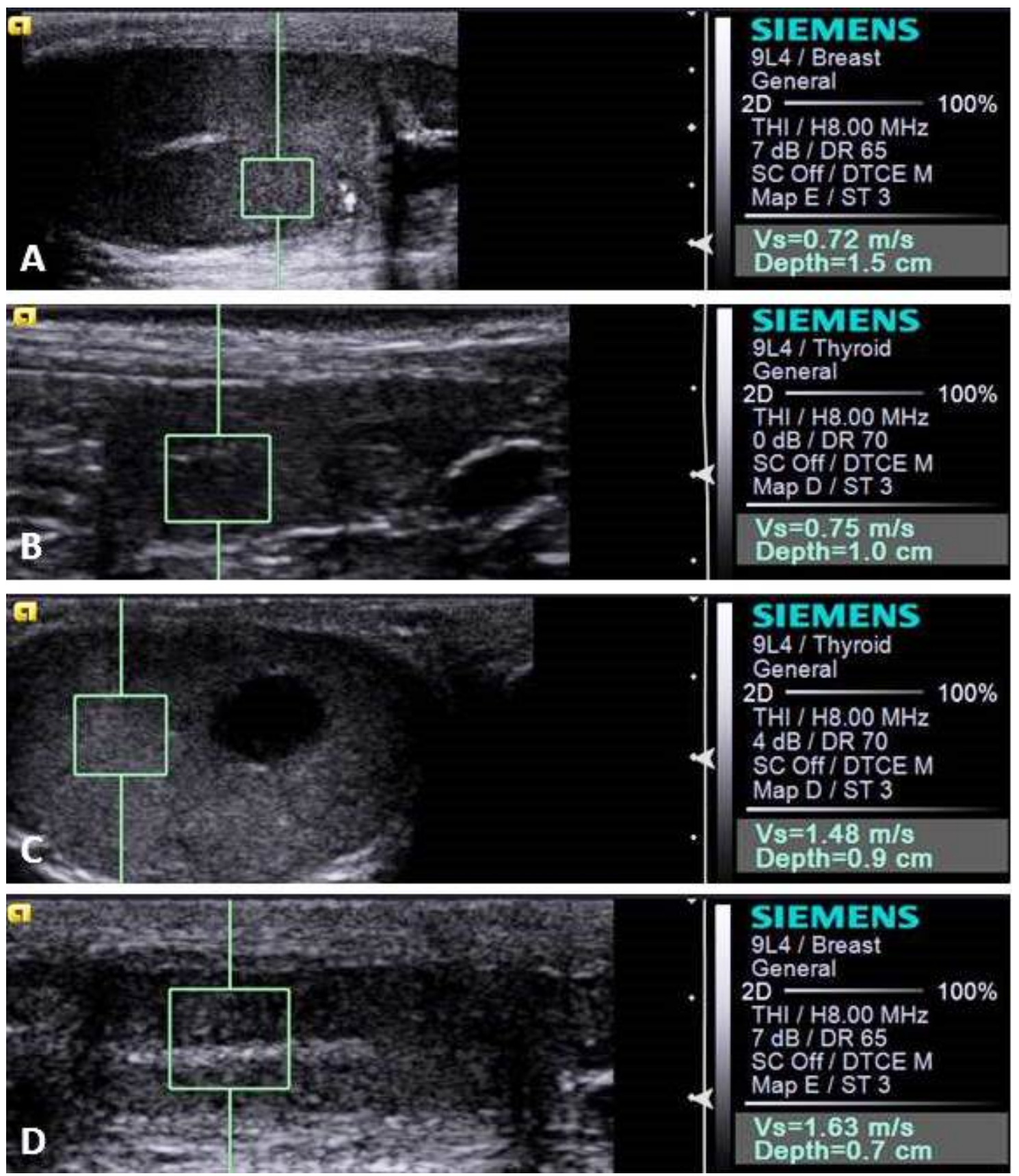

Figure 3. Quantitative ARFI elastography image of testicular disorders in dogs: Note the presence of the calliper in the abnormal testicular parenchyma for shear velocity measurement: (A) testicular degeneration; (B) testicular hypoplasia; (C) testicular cysts; and (D) testicular atrophy. 

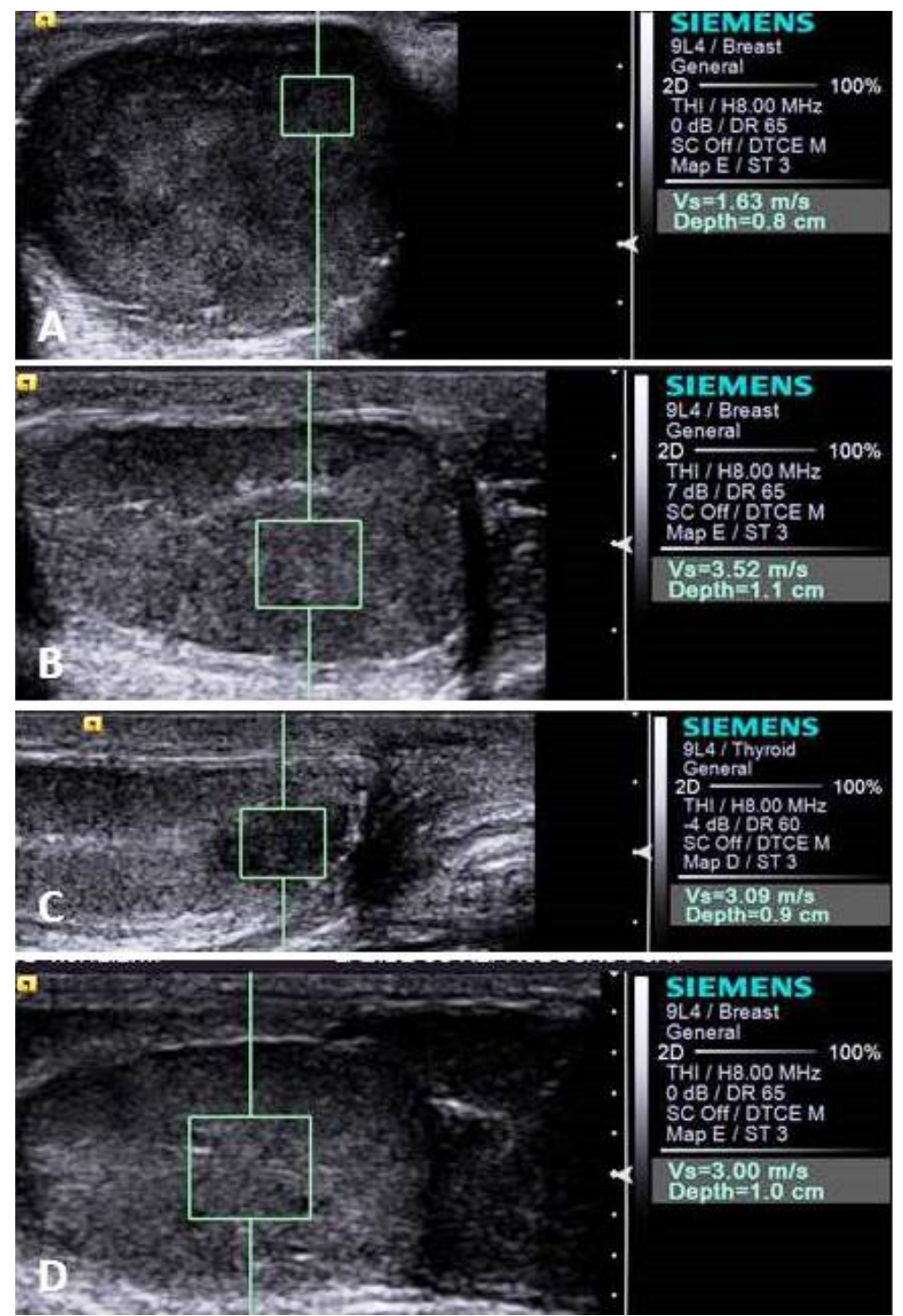

Figure 4. Quantitative ARFI elastography image of testicular disorders in dogs: Note the presence of the calliper in the abnormal testicular parenchyma for shear velocity measurement: (A) orchitis, (B) interstitial cell tumour, (C) sertolioma and (D) leydigoma.

\section{DISCUSSION}

In Veterinary Medicine, Feliciano et al. (2015a) were the first to use ARFI to study the testicular parenchyma of healthy dogs. Similarly, the present study is the first report on the use of the ARFI elastography on the evaluation of testicular abnormalities in dogs. The results obtained for stiffness of the tissues analysed are promising and can help in the diagnosis of the main testicular diseases in dogs, as well as in humans. Studies have demonstrated that elastography can provide auxiliary and important information in the evaluation of testicular lesions, both for detection of small lesions and for differentiation of benign and malignant disorders (Aigner et al. 2012; Goddi et al. 2012; Huang and Sidhu 2012).

Ultrasonography has been considered fundamental in the detection of testicular alterations; however, it does not provide conclusive information on the consistency of the tissues or a definitive diagnosis of lesions (Grasso et al. 2010; Domingos and Salomão 2011; Goddi et al. 2012). In the present study, testicular alterations were detected by B-mode 
ultrasound and the imaging findings corresponded to those previously reported (Domingos and Salomão 2011). However, some testicular diseases, such as inflammation and neoplasia, showed similar ultrasound characteristics making diagnosis difficult. Aigner et al. (2012), when evaluating testicular lesions in humans, obtained considerable values for sensitivity $(100 \%)$, specificity $(81 \%)$ and accuracy (94\%) for elastography when compared to ultrasonography (sensitivity: $100 \%$, specificity: $75 \%$ and accuracy: $92 \%$ ), confirming the importance of this technique and its use combined with ultrasonography.

For qualitative ARFI elastography, it was generally observed that all abnormal testicles had a heterogeneous parenchyma and were not pliable. The neoplastic (focal or diffuse) and inflammatory lesions showed greater stiffness (dark grey) than benign lesions (light grey), as observed by Huang and Sidhu (2012) in humans. These stiffness characteristics were different from those of healthy testicles (six) observed in this study and from those reported by Feliciano et al. (2015a) (homogenous parenchyma, not pliable and of mid-grey tonality).

For quantitative ARFI elastography, the shear velocities obtained for normal healthy canine testicles $(1.30 \pm 0.12 \mathrm{~m} / \mathrm{s})$ were similar to the values obtained by Feliciano et al. (2015a) in dogs (juvenile: $1.28 \mathrm{~m} / \mathrm{s}$, adult: $1.23 \mathrm{~m} / \mathrm{s}$ and senior: $1.23 \mathrm{~m} / \mathrm{s}$ ) and higher than those observed in humans $(0.62$ to $1.01 \mathrm{~m} / \mathrm{s})$ (D'Anastasi et al. 2011), probably due to the fact that dogs have greater fibrous tissue in the testicles.

There was a difference between the shear velocity of healthy testicles and that of abnormal testicles (Table 1), demonstrating stiffness in abnormal tissues. This is the first report of shear velocity of testicular disorders in both Veterinary and human Medicine and can thus be used as reference values for the conditions described.

The values of shear velocity in testicular disorders of dogs can assist in the diagnosis of malignant lesions in this organ by enabling early diagnosis and early treatment of animals. This statement is corroborated by data in human and animal studies (D'Anastasi et al. 2011; Dudea et al. 2011; Feliciano et al. 2015b) in which quantitative ARFI techniques were used to differentiate benign and malignant tumours (rigid and non-pliable tissues with high shear velocity values are indicative of malignancy). In the present study, the benign lesions (cysts, hypoplasia, atrophy, degeneration and inflammation) showed lower shear velocity than malignant lesions (testicular neoplasms).

The histopathological characteristics of each testicular disorder observed in this study can explain the different shear velocity values obtained. Testicular degeneration (tissue destruction) and hypoplasia (development failure or early destruction) are characterized by the loss of the normal cellularity of the testicles (Feldman and Nelson 2004; Domingos and Salomão 2011), leading to minor stiffness of these tissues and, consequently, shear velocity values below the normal range $(0.97 \pm 0.08$ and $0.82 \pm 0.2$ respectively). Testicular atrophy showed shear velocity values above normal $(2.00 \pm 0.35 \mathrm{~m} / \mathrm{s})$ due to the thickening of the baseline membrane of the seminiferous tubules and interstitial fibrosis. In cystic cases, the lesions are limited and do not compromise the adjacent tissue (Domingos and Salomão 2011); therefore, the peri-cystic regions had normal shear velocity $(1.32 \pm 0.18 \mathrm{~m} / \mathrm{s})$

Orchitis is characterized by an inflammatory process that promotes tissue disorganization, fibrin deposition, oedema and cell migration (Nelson and Couto 2006); which may be correlated to the increased stiffness $(2.68 \pm 0.42)$ observed. Conjunctive septa, hyaline and cellular hyperplasia are the main histopathological characteristics of testicular neoplasms (Kennedy and MacLachlan 2002). They increase tissue stiffness and consequently increase shear velocity (interstitial cell tumour: $3.32 \pm 0.65 \mathrm{~m} / \mathrm{s}$, sertolioma: $2.99 \pm 0.07 \mathrm{~m} / \mathrm{s}$ and leydigoma: $2.73 \pm 0.37 \mathrm{~m} / \mathrm{s})$.

It is important to comment on some of the limitations observed this study.

The qualitative and quantitative elastography of the abnormal and normal testes in dogs was performed without difficulty and without sedation. Due to the location of the organ analysed, there was no interference from movements (i.e. respiration) that hindered the acquisition of the measurements, as cited by Holdsworth et al. (2014) during abdominal elastography in dogs. This initial study provides 
important data on the validation of the technique in testicular diseases in dogs; however, a larger study is needed.

\section{CONCLUSION}

Quantitative and qualitative ARFI elastography of testicular disorders in dogs was easily implemented and this study provides important data and baseline reference values for the use of this technique in Veterinary obstetrics and in the diagnosis of the main testicular disorders of animals.

\section{ACKNOWLEDGEMENTS}

The authors would like to thank FAPESP for the research study grant and the Young Researcher grant awarded (2012/16635-2 and 2013/064431).

\section{REFERENCES}

AIGNER, F.; DE ZORDO, T.; PALLWEINPRETTNER, L. et al. Real-time Sonoelastography for the evaluation of testicular lesions. Radiology, v.263, p.584-589, 2012.

BRANDÃO, C.V.S.; MANPRIM, M.; RANZANI, J.J.T. et al. Orchiectomy to reduce the prostatic size: experimental study in dogs. Arch. Vet. Sci., v.11, p.79, 2006.

COMSTOCK, C. Ultrasound elastography of breast lesions. Ultrasound Clin., v.6, p.407-415, 2011.

D'ANASTASI, M.; SCHNEEVOIGT, B.S.; TROTTMANN, M. et al. Acoustic radiation force impulse imaging of the testes: a preliminary experience. Clin. Hemorheol. Microcirc., v.49, p.105114, 2011.

DAVIDSON A.P.; BAKER T.W. Reproductive ultrasound of the dog and tom. Top. Companion Anim. Med., v.24, p.64-70, 2009.

DOMINGOS, T.C.S.; SALOMÃO, M.C. Diagnostics tools of testicular disorders in dogs: review. Rev. Bras. Rrep. Anim., v.35, p.393-399, 2011.

DUDEA, S.M.; GIURGIU, C.R.; DUMITRIU, D. et al. Value of ultrasound elastography in the diagnosis and management of prostate carcinoma. Med. Ultrason., v.13, p.45-53, 2011.

FELDMAN, E.C.; NELSON, R.W. Disorders of the testes and epidymides. In: ETTINGER, S.J.; FELDMAN, E.C. (Eds.). Canine and feline endocrinology and reproduction. Philadelphia: W.B. Saunders, 2004. p.961-977.
FELICIANO, M.A.R.; MARONEZI, M.C.; SIMÕES, A.P.R. et al. Acoustic radiation force impulse elastography of the prostate and testes of dogs: initial results. J. Small Anim. Pract., v.56, p.320-324, 2015 a.

FELICIANO, M.A.R.; MARONEZI, M.C.; CRIVELLENTI, L.Z. et al. Acoustic radiation force impulse (ARFI) elastography of the spleen in healthy adult cats: a preliminary study. J. Small Anim. Pract., v.56, p.180-183, 2015 b.

FELICIANO, M.A.R.; MARONEZI, M.C.; PAVAN, L. et al. ARFI elastography as complementary diagnostic method of mammary neoplasm in female dogs - preliminary results. J. Small Anim. Pract., v.55, p.504-508, 2014.

GODDI, A.; BONARDI, M.; ALESSI, S. Breast elastography: a literature review. J. Ultrasound, v.15, p.192-198, 2012.

GRADIL, C.M.; YEAGER, A.; CONCANNON, P.W. Evaluación de los problemas reproductivos del macho canino. In: CONCANNON, P.W.; ENGLAND, G.; VERSTEGEM III, J.; LINDE-FORSBERG, C. (Eds.). Advances in small animal reproduction. Ithaca, NY: International Veterinary Information, 2007.

GRASSO, M.; BLANCO, S.; RABER, M. et al. Elasto-sonography of the testis: preliminary experience. Arch. Ital. Urol. Androl., v.82, p.160-163, 2010.

HOLDSWORTH, A.; BRADLEY, K.; BIRCH, S. et al. Elastography of the normal canine liver, spleen and kidneys. Vet. Radiol. Ultrasound, v.55, p.620-627, 2014.

HUANG, D.Y.; SIDHU, P.S. Focal testicular lesions: colour doppler ultrasound, contrastenhanced ultrasound and tissue elastography as adjuvants to the diagnosis. Br. J. Radiol., v.85, p.S41-S53, 2012.

KENNEDY, P.C.; MACLACHLAN, N.J. Tumours of the genital systems. In: MEUTEN, D.J. (Ed.). Tumors in domestic animals. 4.ed. Blackwell: Iowa, 2002. p.547-575.

LORENZ, A.; ERMET, H.; SOMMERFELD, H.J. et al. Ultrasound elastography of the prostate. A new technique for tumor detection. Ultraschall Med., v.21, p.8-15, 2000.

NELSON, R.W.; COUTO, C.G. Medicina interna de pequenos animais. Rio de Janeiro: Elsevier, 2006. $1324 \mathrm{p}$.

SOUZA, M.B.; SILVA, L.D.M. Two-dimensional, Doppler and contrast enhanced ultrasonography on testicular evaluation: from man to animal. Rev. Bras. Reprod. Anim., v.38, p.86-91, 2014. 